\title{
«HE SIGHED FROM HIS HEART AND BEGAN TO GATHER SOLDIERS»: EMOTIONS IN RUSSIAN POLITICAL NARRATIVES
}

Russian chronicles represent emotions as a driving force of political actions, as reasons for starting and ending wars, for making and breaking alliances, and for other political decisions. Moreover, emotions often assume a normative, prescriptive character, as in Iaroslav's «Testament», which gives princes the precepts to live in brotherly love, to respect seniority, and to avoid hatred ${ }^{1}$. To note the primitive and inefficient character of a «political theory» based on such a feeble foundation as sentiments of family love has long been a commonplace for Rus scholars ${ }^{2}$. In this respect, they have been no different from Western medievalists who, until the 1990s, shared Marc Bloch's view of the emotional instability of medieval society and the resulting irrationality of medieval politics ${ }^{3}$. However, the paradigm of childlike medieval people dominated by uncontrolled emotional outbursts is now abandoned, and scholars connect historical concepts of emotions with concepts of social relationships and institutions. Emotions history became so prominent that by the early 2000 s, some historians were «tired» of hearing about the role of emotions in medieval politics ${ }^{4}$. This blooming of

${ }^{1}$ PSRL. T. 2. Moscow, 1999. Stb. 149-150.

${ }^{2}$ The first, to my knowledge, ironic reference to the «political theory» based on family sentiments was made in: Hrushevskiy M. S. Istoriya Ukrainy-Rusi. Lviv, 1905. Vol. 2. P. 47-48.

${ }^{3}$ Bloch M. 1) Feudal Society. Chicago, 1961. P. 73; 2) La sociéte féodale: La formation des liens de dépendance. Paris, 1949.

${ }^{4}$ Davies $R$. The Medieval State: The Tyranny of a Concept? // Journal of Historical Sociology. 2003. Vol. 16. P. 280. See also: Rosenwein B. 1) Even the Devil (Sometimes) Has Feelings // The Haskins Society Journal. 2005. Vol. 14. P. 1-14; 2) Eros and Clio: Emotional Paradigms in Medieval Historiography // Mediävistik im 21. Jahrhundert: Staat und Perspektiven der internationalen und interdisziplinaren Mittelalterforschung. Munich, 2003. P. 428; White S. The Politics (C) C.-Петерб. гос. ун-т, 2016; (C) Yu. Mikhailova, 2016 
emotions history is connected with chronologically preceding developments in psychology: cognitive and social constructionist theories came to view emotions as aspects of interactions between individuals and their social environments. ${ }^{5}$. In the words of Barbara Rosenwein, a leading historian of emotions in the medieval West, «the new theories invite us to reconsider our sources anew» ${ }^{6}$. This is the task of the present article in regards to the Russian sources.

\section{The Evolution of the Representation of Emotions in the Primary Chronicle}

The early entries of the Primary Chronicle rarely verbalize emotions. In this respect, they are similar to sagas, where feelings must often be inferred from literary context ${ }^{7}$. In the Chronicle, the context is typically provided by representing the characters' gestures and direct speech: when Sviatoslav received a gift of gold and silk, he «said to his men, looking the other way, 'Put these away'», but having received weapons, he «started to praise and to love them and kissed the emperor», who had sent the gift ${ }^{8}$. The «kiss» was purely symbolic, since the emperor was not physically present. The chronicler describes the gesture of love and gratitude as a way to convey Sviatoslav's feelings about the gift of weapons, just as Sviatoslav's words and the direction of his sight showed that gold and silk disappointed him.

The later parts of the Chronicle are more explicit in the treatment of emotions. For example, in the famous account of Vasilko' blinding, David, who invited Vasilko for a breakfast with the intention to capture him, «had neither voice nor hearing, because he was terrified and had deception in his heart» ${ }^{9}$. The description of the external behavior is accompanied by the explicit naming of the emotion that was causing the behavior.

This change in the representation of feelings occured as the accounts of interprincely relations became more detailed and complex. As was typical of early medieval society, these relations were regulated by implicit, unwritten norms, which Gerd Althoff deemed «rules of play» (Spielregeln) of medieval politics and which included public display of emotions ${ }^{10}$. Starting in the late eleventh century, we see that not only the dramatic narrative of Vasilko's blinding, but regular accounts of political events, such as the 1097 Liubech conference, are saturated with emotion talk. The princes who gathered in Liubech noted that the Cumans «rejoiced» because of the internal strife in Rus and decided to stop their hostilities, which

of Anger // Anger's Past: The Social Uses of an Emotion in the Middle Ages. Ithaca, 1998. P. 131; Roche T. The Way Vengeance Comes: Rancorous Deeds and Words in the World of Orderic Vitalis // Feud, Violence and Practice: Essays in Medieval Studies in Honor of Stephen D. White. Burlington, 2010. P. 125-126; Hinterberger M. Emotions in Byzantium // A Companion to Byzantium. Malden MA, 2010. P. 123-134.

${ }^{5}$ Rosenwein B. 1) Eros and Clio... P. 435; 2) Problems and Methods in the History of Emotions // Passions in Context: International Journal for the History and Theory of Emotions. 2010. Vol. 1. P. 1-32.

${ }^{6}$ Rosenwein B. Eros and Clio... P. 441.

${ }^{7}$ Miller W. Humiliation: And Other Essays on Honor, Social Discomfort, and Violence. Ithaca, New York, 1995. P. 108.

${ }^{8}$ PSRL. T. 1. Moscow, 1999. Stb. 71.

${ }^{9}$ PSRL. T. 1. Stb. 259.

${ }^{10}$ Althoff G. Spielregeln der Politik im Mittelalter. Kommunikation in Frieden und Fehde. Darmstadt, 1997. 
made «all people» glad, and only the Devil was sad ${ }^{11}$. It was why he instigated David's men to slander Vasilko, claiming that the latter entered into a conspiracy against both David and the Kievan prince Sviatopolk. When David shared this accusation with Sviatopolk and claimed that Vasilko had been behind the mysterious murder of Sviatopolk's brother, Sviatopolk «was confused in his mind» and was not sure how to react. Finally, he «felt pity» for his brother and for himself, and gave his consent to the blinding ${ }^{12}$. Since, in the end, David was punished for blinding Vasilko, but Sviatopolk was not, the chronicler probably mentions Sviatopolk's confusion and pityas alleviating circumstances ${ }^{13}$.

When Vladimir Monomakh learned about the blinding, he «was terrified and wept profusely». He then informed two other princes who «were very sad and began to weep» ${ }^{14}$. Here, again, the visible behavior — crying — is explained by naming the emotions behind it. The difference with the passage about the fateful breakfast is that David was not able to carry on a conversation in spite of himself and tried in vain to hide his confusion, while the weeping princes did not make any attempt to hide their tears.

\section{Display of Emotions and the «Civilizing Process»}

The description of princes weeping over Vasilko's blinding exemplifies the type of medieval narrative that used to be interpreted as evidence of medieval people's inability to control their emotions. Such interpretations often employed Norbert Elias's influential concept of the «civilizing process», which gradually brought about the degree of self-control necessary for abstaining from «weeping profusely» after receiving bad news ${ }^{15}$. As Althoff points out, this picture of a medieval society not yet affected by the «civilizing process», a society in which emotions allegedly had a free rein, is in stark contradiction to the medieval moral literature written in the tradition of Christian ethics that preached self-control and prohibited unrestrained emotions. Kings, in particular, were encouraged to control their feelings ${ }^{16}$.

The same is true for the Russian princes. Monomakh, in his Instruction, argues that a «pious man» should control his anger, laughter, facial expression, and his mind and body in general. As for his own sons, he wants them to control their inner thoughts as well: when riding a horse, they should keep calling silently, «Lord, have mercy on me!». This is better «than thinking idle thoughts while riding ${ }^{17}$. Arguably, if we see the same Monomakh bursting into tears on every other page of the chronicle, we should seek a different explanation than his inability to control his emotional outbursts.

\footnotetext{
${ }^{11}$ PSRL. T. 1. Stb. 256-257; cf.: Rosenwein B. Even the Devil... P. 9-10.

${ }^{12}$ PSRL. T. 1. Stb. 257-258. On the murder, see: Litvina A. F., Uspenskiy F. B. O vozmozhnykh motivakh odnogo politicheskogo ubiystva (XI v.) // Vspomogatel'nye istoricheskie distsipliny v sovremennom nauchnom znanii: Materialy XXVIII Mezhdunarodnoy nauchnoy konferentsii. Moscow, 2016. P. 34-40.

${ }^{13}$ PSRL. T. 1. Stb. 257-258, contra Litvina A. F., Uspenskiy F. B. O vozmozhnykh motivakh... P. 36. ${ }^{14}$ PSRL. T. 1. Stb. 262; T. 2. Stb. 236

${ }^{15}$ Althoff G. Spielregeln der Politik... P. 260; Elias N. The Civilizing Process: Sociogenetic and Psychogenetic Investigations. Boston, 2000. - This work was first published in 1939; it became very influential when it was republished in 1969.

${ }^{16}$ Althoff G. Spielregeln der Politik... P. 265.

${ }^{17}$ PSRL. T. 1. Stb. 242-245.
} 
Western medievalists argue that public display of emotions performed important social and political functions. Thus, the display of anger often involved «a quasi-juridical appraisal of the act and of the person or persons deemed responsible for it» ${ }^{18}$. The princes who learn about Vasilko's blinding display terror and grief rather than anger; however, the presentation of their emotions has clear overtones of «a quasi-juridical appraisal». Significantly, Monomakh's emotional expression is stronger than that of the other two princes: he wept «profusely» and was «terrified», while they were merely «very sad». Correspondingly, it is Monomakh who gives an appraisal of the crime and organizes the collective action against the perpetrators, calling on princes, «Let us correct this evil ... if we do not correct it, more evil will arise among us, and brother will start stabbing brother to death, and the Rus Land will perish» ${ }^{19}$. Thus, the account of the princes' emotional response to Vasilko's blinding serves as a way to establish Monomakh's leadership. The next passage that represents Monomakh as crying in public adds a new facet to Monomakh's authority.

When the expedition against the blinders of Vasilko reached Kiev, Sviatopolk attempted to flee, but the Kievans stopped him and sent Monomakh's step-mother and the metropolitan with a plea not to attack the city. Monomakh «burst into tears» and «inclined to the plea», because he always honored and obeyed his step-mother «as his own mother» ${ }^{20}$.

\section{Maternal Imagery and THE «Emotional Community» OF Vladimir MonomakH}

Monomakh's tearful response to the plea of a woman whom he «honored as his mother» is consistent with the representation of his «emotional community», that is, a group, members of which «value — or devalue — the same or related emotions» ${ }^{21}$. The emotional community of the princes acting together under Monomakh's leadership is characterized by intense sentiments of family love. In this respect, it is similar to Rosenwein's description of the Austrasian kings of Gaul, who practiced «effusive affirmations of family feeling, love, and sweetness». This practice «may be related to the royal family structure and its fragility ... Brothers and half-brothers shared a kingdom ... However fragmented it may have been in reality, it was understood to be a whole. Its rulers ... needed the tools and metaphors of family bonding to keep this myth in place» ${ }^{22}$.

This bears striking resemblance to the situation in Rus ${ }^{23}$. It is easy to see why the Austrasianstyle rhetoric of family bonding had to be an essential part of a dynastic culture where there was no crowned king and no clear rules of succession. In the Russian case, emotions associated with family bonding not only helped to hold together the extended dynasty, but also played an important role in articulating the position of leadership. To claim the leading role in the «joint enterprises» ${ }^{24}$ of the dynasty, a prince was to demonstrate how much he cared about the well-being of the extended kin and the Rus Land as a whole. Monomakh's leading role in

\footnotetext{
${ }^{18}$ White $S$. The Politics of Anger. P. 140.

${ }^{19}$ PSRL. T. 1. Stb. 262; T. 2. Stb. 236.

${ }^{20}$ PSRL. T. 1. Stb. 263-264; T. 2. Stb. 237-238.

${ }^{21}$ Rosenwein B. Emotional Communities in the Early Middle Ages. Ithaca, New York, 2007. P. 2.

${ }^{22}$ Rosenwein B. Emotional Communities... P. 129.

${ }^{23}$ See: Nazarenko A. V. Rodovoy syuzerinetet Ryurikovichey nad Rus'yu (X-XI vv.) // Drevnie gosudarstva na territorii SSSR, 1985 god. Moscow, 1986. P. 149-57.

${ }^{24}$ Franklin S., Shepard, J. The Emergence of Rus', 750-1200. New York, 1996. P. 276.
} 
the aftermath of Vasilko's blinding is apparently connected with his tears over the prospect of «brother stabbing brother» and the ruin of the Rus Land.

We have also seen that the chronicler underscores Monomakh's respect for a mother figure. Not only were his feelings towards the step-mother appropriate for the emotional community, which placed high value on family love, but they were also consistent with an important aspect of Monomakh's image. To understand this aspect better, we need to turn again to Rosenwein's discussion of the Gaulish emotional communities. She contrasts the warm emotional style of the Austrasian court with the Neustiran court of Clothar II, who took over in 613 and who promoted a new and colder emotional sensibility. One feature of the Neustrian emotional community was deep suspicion of mothers with their allegedly uncontrolled emotions. Clothar II, arguably an illegitimate child, may have «found it politically important to downgrade mothers altogether». The cold emotional style of Clothar's court was a part of this «downgrading of mothers», who were associated with «warmer emotional expression» ${ }^{25}$. Was it possible then that the high regard for mothers was a part of Monomakh's intensely emotional style? Monomakh's mother was a Byzantine princess; he proudly refers to «my mother of the Monomakhus family» ${ }^{26}$. If it is true that Clothar's alleged illegitimacy caused him «to downgrade mothers altogether», Monomakh's imperial mother could have caused him and his chroniclers to stress the importance of mothers in general.

Indeed, maternal imagery permeates the representations of Monomakh in the chronicles. His obituary states that people «wept over him just as children weep over their father or mother». Mourning a prince as a father is quite common; however, a reference to a mother is unique to Monomakh's obituary. By the same token, Monomakh gave monks «food and drink like a mother feeding her children»; when seeing any of them behaving inappropriately, «he did not condemn them, but dealt with them lovingly» ${ }^{27}$.

Arguably, the significance of motherly features in Monomakh's image appears to go beyond stressing his prestigious Byzantine connections. Medieval religious writers applied maternal imagery to male authority figures when they felt «the need to supplement authority with love», because the prevailing stereotypes associated «emotionality and love» with the female or maternal ${ }^{28}$. These «maternal» characteristics are present in Monomakh's own texts, especially in the well-known letter to his cousin and rival Oleg, where Monomakh declares that he would not pursue revenge for the death of his son in a battle against Oleg and discusses their territorial disputes. However, these political matters come up only towards the end of the letter, while the bulk of the text is devoted to the lyrical description of Monomakh's feelings: grief over the death of his son, a regret that he was not present at his son's wedding, his desire to embrace his widowed daughter-in-law and mourn together ${ }^{29}$. In his Instruction, Monomakh claims that he stopped fighting Oleg because he «felt pity for the Christian souls

${ }^{25}$ Rosenwein B. Emotional Communities... P. 130, 150, 192.

${ }^{26}$ PSRL. T. 1. Stb. 240.

${ }^{27}$ PSRL. T. 1. Stb. 263-264; T. 2. Stb. 237-238.

${ }^{28}$ Bynum C. Jesus as Mother and Abbot as Mother: Some Themes in Twelfth-Century Cistercian Writing // Jesus as Mother: Studies in the Spirituality of the High Middle Ages. Berkeley, 1982. P. $148,155$.

${ }^{29}$ PSRL. T. 1. Stb. 252-255. 
and for the burning villages and monasteries $\rangle^{30}$. Monomakh's authority appears to be not so much «supplemented by love», as based on it.

\section{The Emotional Vocabulary of The Twelfth-Century Chronicles}

Love is one of the few emoitons actively and repeatedly used in Russian chronicles and in high medieval Western narratives of aristocratic politics. According to Stephen White, the Western vocabulary of political emotions, in addition to love, includes «anger, grief, shame, hatred or enmity, fear and joy» ${ }^{31}$. The same vocabulary is used to represent emotions in the Russian chronicles. Furthermore, in both Old French and Latin the notions of grief and anger often «merge to form a single emotion - a kind of sad anger, angry sadness» ${ }^{32}$. In Russian texts, this emotion is expressed by words with the root zhal, the preposition na and the direct object in the accusative.

Zhal-words normally stand for «pity», «grief», «sorrow», but with the preposition na they convey White's «sad anger». The best example of how the prepositions affect the meaning of zhal-words is found in the famous account of Igor's campaign in 1185. As is well-known, Igor went against the Cumans without the permission of the Kievan prince Sviatoslav and was defeated and captured. Sviatoslav thus summarizes his feelings: «Just as I was angry at (zhal mi biashet' na) Igor, I now feel as much and [even] more pity for (zhaluiu po) Igor $)^{33}$. «Sad anger» experienced by Sviatoslav when he learned about the unauthorized campaign is expressed by zhal na. $\mathrm{Na}$ changes to po when Sviatoslav's anger changes to pity ${ }^{34}$.

The most typical words for «anger», however, are gnev and its derivatives. A negative feeling, which is close to anger, but not as strong, is conveyed by expressions with the word «heart (serdtse)»: to be displeased by somebody is «to have a bad (or heavy) heart at» him, while making someone displeased is as «to harm his heart» or to cause «pereserdie» ${ }^{35}$.

Anger and displeasure may lead to hatred (nenavist) ${ }^{36}$. Grief, fear, and shame are also on the list of negative emotions identified by White in the Western sources; Russian chronicles have pechal, unynie, skorb, tuga for «grief» and sorom for «shame». Fear is expressed by strakh, trepet, uboiatisia, upoloshitesia, uzhasatisia. Words with the root uzhas (terror) may refer to either fear or moral shock. Thus, when Monomakh was «terrified» by the blinding of Vasilko, he was shocked and outraged rather than scared, but when Igor was preparing to escape from Cuman captivity and got up at night «terrified» (uzhasen), the word clearly refers to fear ${ }^{37}$.

The positive emotions that White identified in the high medieval Western sources are limited to love and joy. The same is true for Russian chronicles. Love is expressed by words with the root liub, and also by the expression «to be dear» (mil). Liub-words can take multiple meanings, including Christian love or personal affection ${ }^{38}$. However, most uses of «love» are

${ }^{30}$ PSRL. T. 1. Stb. 249.

${ }^{31}$ White $S$. The Politics of Anger. P. 134.

${ }^{32}$ White $S$. The Politics of Anger. P. 135.

${ }^{33}$ PSRL. T. 2. Stb. 645.

${ }^{34}$ See also: PSRL. T. 1. Stb. 318; T. 2. Stb. 364, 386, 499, 513, 539, 544, 570, 624.

${ }^{35}$ PSRL. T. 1. Stb. 379; T. 2. Stb. 241, 450, 609.

${ }^{36}$ PSRL. T. 1. Stb. 161, 403; T. 2. Stb. 219.

${ }^{37}$ PSRL. T. 1. Stb. 262; T. 2. Stb. 236, 651.

${ }^{38}$ PSRL. T. 1. Stb. 246; T. 2. Stb. 198, 207. 
political. When one prince threatens another, «If you do not want to accept me into love ( $v$ liubov'priiati) ... I will burn your land $»^{39}$, this «love» surely is not affection. The context shows that «accepting into love» in this particular case means to enter into an alliance with the threatening prince on his conditions ${ }^{40}$. By the same token, sending envoys «with love» amounts to a proposal of alliance ${ }^{41}$. When two princes «entered into love», the next thing they did was a joint attack on a common enemy ${ }^{42}$. Their «love» was a military alliance. Similarly, several parties planning a joint raid into neighboring territories «established (polozhisha) love between themselves that they will all gather in the winter [and go] against either the Lithuanians or the Chud» ${ }^{43}$.

Yet another meaning of love referred to peace talks or a peace treaty, as in the message the Olgovichi sent to Vsevolod Bolshoe Gnezdo after he had invaded their lands: "If you like to make a just agreement and to be in love with us, we do not seek to avoid love ... However, if you have contrived something else, we do not seek to avoid that either, and may God do his judgment» ${ }^{44}$. Apparently, the gist of this message is a proposition to start negotiations, but at the same time to make it clear that the Olgovichi are not afraid to fight Vsevolod if need be. «Something else» that Vsevolod might have contrived refers to his possible plans of a full-scale war with the Olgovichi, an alternative to which is «to be in love» with them ${ }^{45}$. On other occasions, «love» is directly identified with «peace», with the two words being used interchangeably. Correspondingly, «not to have love» signifies hostilties or a military conflict ${ }^{46}$.

The semantic field of Russian «love» is thus rather large. Remarkably, it is practically identical to that of the «love» in Western high medieval sources. Scholarly discussions of «love» in Western texts invariably begin with the explanation that it is not to be understood in its «modern psychological sense» and does not «always imply personal affection or emotional attachment». + Amer someone means to keep or make peace, to form an alliance with this person, or else to be faithful to him; amor stands for «alliance» and «loyalty» ${ }^{47}$.

Conversely, «not to love» someone is to have hostilities with this person. When a chanson de geste character states that he will not amer another character, Bernier, until he has destroyed or exiled him, this, of course, does not mean that he will feel any affection for Bernier after he destroys him. What he means is that he will only stop his hostilities when Bernier is dead or exiled ${ }^{48}$. In an Anglo-Norman chronicle the idea of being somebody's sworn enemy is

${ }^{39}$ PSRL. T. 2. Stb. 386.

${ }^{40}$ The threatening prince is Iziaslav Mstislavich trying to forge what is known as his «duumvirate» with Viacheslav Vladimirovich, to which Viacheslav initially objected.

${ }^{41}$ PSRL. T. 2. Stb. 513.

${ }^{42}$ PSRL. T. 2. Stb. 513-514.

${ }^{43}$ N1L. P. 40.

${ }^{44}$ PSRL. T. 2. Stb. 698-699.

${ }^{45}$ PSRL. T. 2. Stb. 393.

${ }^{46}$ PSRL. T. 1. Stb. 344; T. 2. Stb. 543, 585-586; N1L. P. 55

${ }^{47}$ Débax $H$. La féodalité languedocienne aux Xie - XIIe siècles: serments, sommages et fiefs dans le Languedoc des Trencavel. Toulouse, 2003. P. 126; Jones G. The Ethos of the Song of Roland. Baltimore, 1963. P. 40; Cheyette F., Howell Chickering H. Love, Anger, and Peace: Social Practice and Poetic Play in the Ending of Yvain // Speculum. 2005. Vol. 80. P. 84.

${ }^{48}$ Jones $G$. The Ethos... P. 36-37. 
expressed by l'aime pas de fei (literally «does not love him by oath»), and the expression «sends with love» (mande par amur) means an invitation to join a military alliance, just as sending $s$ liboviu does in Russian sources ${ }^{49}$.

The use of the same word for the feeling of affection, Christian love, and political cooperation reflects the lack of differentiation between the private and public spheres of life typical of pre-modern societies ${ }^{50}$. It is all the more interesting, therefore, to note cases when the word choice for «love» reflects a differentiation between the public and the private. It appears that the word mil (dear) refers primarily to the emotions experienced in the private sphere. Thus, the chronicler uses this word to explain why Iaroslav of Galich loved his illegitimate son Oleg more than his other son: «Oleg was dear to him because he was Nastasia's», that is, he was from Iaroslav's mistress ${ }^{51}$. Iaroslav's feelings towards Nastasia and her son had political implications - he bequeathed the better volost to him, not to the legitimate heir — but the use of mil rather than any word with the root liub seems to indicate that Iaroslav's attitude towards his sons originated in the private sphere.

Another example of this usage of a mil-word is found in the famous account about the marriage of the eight-year-old Verkhuslava. The wedding sealed the long-awaited reconciliation between the two major branches of the Monomakhovichi, the southern Kievbased and the northern Suzdalia-based. Riurik, the senior southern Monomakhovich, asked the Suzdalian prince Vsevolod to give his daughter in marriage to Riurik's son. The marriage was too significant politically to delay; therefore, the request was granted in spite of the bride's tender age. Verkhuslava was sent off to Kiev, «and father and mother rode with their dear daughter for three leagues and wept over her because she was dear to them and was [so] young». On the other hand, when Verkhuslava's entourage returned back to Suzdalia and presumably gave an account about the gifts and honors bestowed on Verhkuslava and about her splendid wedding, «there was great joy for the grand prince and princess and for all the people $»^{52}$. The chronicler seems to differentiate between the public and private spheres of life of the princely family: private sadness about the separation from the «dear daughter» and public joy at the successful political marriage. The unusual attention paid to the private feelings of Vsevolod and his wife might be explained by the chronicler's desire to stress the great sacrifice they made for the sake of peace and unity.

This brings us to joy, the last on our list of emotions found in both Russian and Western sources. It is expressed by words with the roots rad and vesel; the latter connote public display of joy, which plays an important role in Russian chronicles, as does display of grief53. Grief and joy have «a propensity to circulate among friends, who should share it», in both Russian chronicles and high medieval French and Anglo-Norman political narratives, where display of emotions makes part of «a relatively stable, enduring discourse» of disputing, feuding,

${ }^{49}$ Jordan Fantosme's Chronicle. New York, 1981. P. 10, 20.

${ }^{50}$ On public and private spheres, see: Habermas J. The Structural Transformation of the Public Sphere: An Inquiry into a Category of Bourgeois Society. Cambridge, 1991. — On pre-modern societies, see, e. g.: Stuard S. Women in Medieval Society. Philadelphia, 2012; McSheffrey Sh. Marriage, Sex and Civic Culture in Late Medieval London. Philadelphia, 2006.

${ }^{51}$ PSRL. T. 1. Stb. 657.

${ }^{52}$ PSRL. T. 1. Stb. 658-659.

${ }^{53}$ E. g., PSRL. T. 2. Stb. 340, 359, 369. 
and competition for honor, for which White coined a term «script» ${ }^{54}$. White's «scripts» have remarkable similarities with the patterns of princely behavior found in the Russian chronicles.

Thus, «when a noble is successful in the competition for honor» by winning battles, obtaining powerful allies, or gaining status and riches, «he should have joy and show it» ${ }^{55}$. Russian princes also show joy when they return «with honor and glory» from victorious battles, ascend to their rightful thrones, and generally proclaim their political success ${ }^{56}$. For example, the chronicle entry containing information about the Third Crusade and other important events also reports the joy that two princes, Sviatoslav and Riurik, had on a hunting trip. The joyous hunt merited an inclusion among the most important events of the year because it signified the princes' success in concluding an agreement that ended their fighting for the Kievan throne. The conflict had started after Sviatoslav, in violation of his oath on the Cross, had made a surprise attack on Riurik's brother while the latter was hunting ${ }^{57}$. Thus, the chronicler implicitly contrasts two hunts: the one, during which a treacherous attack started a war, and the other that celebrated mutual love and joy of erstwhile enemies turned legitimate co-rulers.

However, the most common way to «have joy and show it» was feasting and gift-giving. The normative dimension of joy displayed during political feasts is clearly seen from the account about David of Smolensk invited to Kiev by his brother, the Kievan prince. The passage proclaims David's success in the «competition for honor» by listing banquets and gifts which he gave and received in Kiev. When David feasted and exchanged gifts with his brother and with the elite Kievans, they all were in great joy. At the dinner with the Kievan monks, however, only David «was joyous», but not his guests: to rejoice at a dinner was probably not befitting a monk. Finally, when David invited the Black Caps, neither dinner nor gifts made them joyous, and David did not rejoice while dining with them either. Instead, they simply «drank much (popishasia) ${ }^{58}$. Should we infer that David and the Black Caps did not have a good time or that the Black Caps were less pleasant company than the Kievans? Rather, the absence of «joy» shows that the Turkic federati, in the eyes of the author of this passage, were not a part of the relationships based on the shared notion of honor that bound Russian Christian upper classes; therefore, the imperative «to have joy and to show it» did not apply to them. All other parties mentioned in the passage followed the «script» identified by White for the Western nobles celebrating their success ${ }^{59}$.

${ }^{54}$ White S. The Politics of Anger. P. 142. See also: Hyams P. Was There Really Such a Thing as Feud in the High Middle Ages? // Vengeance in the Middle Ages: Emotion, Religion and Feud. Farnham, 2010. P. 160; Roche T. The Way Vengeance Comes... P. 125, 127.

${ }_{55}$ White $S$. The Politics of Anger. P. 142.

${ }^{56}$ E. g., PSRL. T. 1. Stb. 376, 469; T. 2. Stb. 312, 327, 441, 454, 471, 504, 528.

${ }^{57}$ PSRL. T. 2. Stb. 614-615.

${ }^{58}$ PSRL. T. 2. Stb. 681-682.

${ }^{59}$ See also: Mikhailova Yu. «Christians and Pagans» in the Chronicles of Pre-Mongolian Rus: Beyond the Dichotomy of «Good Us» and «Bad Them»// Geschichte der Slavia Asiatica: Quellenkundliche Probleme. Leipzig, 2013. P. 77. - For more information on the chronicle accounts about feasts see: Lukin P. V. Prazdnik, pir i veche: k voprosu ob arkhaicheskikh chertakh obshchestvennogo stroya vostochnykh i zapadnykh slavyan // Feodalizm: ponyatie i realii. Moscow, 2008. P. 163-179. — On feasts in medieval Europe, see: Feasts and Gifts of Food in 
Conversely, when nobles «lose honor by losing land, friends, or battles» or «by suffering insults and injuries, ... their joy should turn to shame, which they display as grief or anger» and then «unleash their anger at the enemies who shamed them and for whom they display hatred and loathing» expressed through aggressive acts ${ }^{60}$. This is exactly what Russian princes did in similar circumstances. For example, when Yury Dolgorukii's fortress was burned by an adversary, he «sighed from his heart and began to gather soldiers»; he then vowed to burn the adversary's property «in equal measure (sia otozhgu protivu)» ${ }^{61}$. Thus, first of all, Yury displays his grief by sighing, and the chronicler finds it important to record this sigh. Then, he gathers soldiers and declares his intention to avenge himself adequately.

If a prince was not able to avenge his loss of honor himself, he followed another «script»: "If the shamed, grieving, angry victim needs help from a superior in taking vengeance against his enemies, he should approach him dolefully, tearfully, and deferentially» ${ }^{62}$. This is exactly what the son of the same Yury did after he suffered dishonor from another prince: he «prostrated himself (udar chelom)» before his father and implored him to launch a campaign to avenge his dishonor. Yury, «having pity for his son's shame», fulflled the request ${ }^{63}$.

Alternatively, a wronged noble in a position of power could choose to «forgive his anger», an expression that has a Russian parallel otdati gneva. In this «script», a disputant's anger abates after he makes peace with his enemies, «in which case anger and enmity should turn into love», a development regularly reported in Russian chronicles as well ${ }^{64}$.

A comprehensive comparative analysis of political uses of emotions in Russian and Western sources is outside of the scope of this article. The goal of the brief overview offered here is to suggest that «rules of play» in Rus and in the medieval West may have more parallels than is generally recognized.

Данные о статье

Автор: Михайлова, Юлия Александровна - преподаватель, Институт горного дела и технологий Нью-Мексико, Нью-Мексико, США, yulia.mikhailova@nmt.edu

Заголовок: «He Sighed from His Heart and Began to Gather Soldiers»: Emotions in Russian Political Narratives [«Он вздохнул в сердце своем и начал собирать солдат»: Эмоции в русском политическом нарративе]

Резюме: В статье рассматривается лексика, которую древнерусские летописцы употребляют для описания эмоциональных состояний, и демонстрируется ее близость аналогичной латинской и старофранцузской лексике. В текстах XI-XII вв., которые можно определить как «политические нарративные источники» (летописи, хроники, записи судебных диспутов между членами социальной верхушки и т. п.), регулярно встречается один и тот же, относительно ограниченный, набор эмоций, общий для Руси и Запада. Помимо анализа лексики, статья затрагивает вопрос о политических и социальных функциях публичной демонстрации эмоциональных состояний. Вопрос этот, всесторонне изученный применительно к различным периодам западноевропейского Средневековья, в первый раз рассматривается на древнерусском материале. Автор прилагает к междукняжеским отношениям понятие «правил игры

Medieval Europe: Ritualised Constructions of Hierarchy, Identity and Community, special issue of the Journal of Medieval History. 2011. Vol. 37. P. 1-124; Heal F. Hospitality in Early Modern England. Oxford, 1990. P. 1-22.

${ }^{60}$ White $S$. The Politics of Anger. P. 142-144.

${ }^{61}$ PSRL. T. 2. Stb. 455-456.

${ }^{62}$ White $S$. The Politics of Anger. P. 144.

${ }^{63}$ PSRL. T. 2. Stb. 373-374.

${ }^{64}$ White S. The Politics of Anger. P. 144; PSRL. T. 2. Stb. 418, 687-688, 697. 
(Spielregeln)», предложенное немецким ученым Гердом Альтхоффом и оказавшее большое влияние на западную медиевистику. «Правила игры» представляли систему имплицитных, подразумеваемых норм, которые регулировали общественные отношения в те периоды, когда не существовало развитого писаного права и разветвленного государственного аппарата. Они выражались через ритуализированное поведение, включавшее в себя как вербальные, так и невербальные способы коммуникации. Эти формы ритуализированного поведения, или поведенческие стереотипы, зачастую заключались в публичном выражении эмоций. Так, русские и западные летописцы считали нужным сообщать своим читателям о слезах и тяжелых вздохах, которые испускали описываемые ими персонажи, или о том, как весело им было на пиру или на охоте. Западные медиевисты показали, что подобные сообщения несли в себе определенную политическую нагрузку. В статье рассматриваются параллели между функциями, которые выполняли описания эмоций в западных и древнерусских источниках, и высказывается предположение, что русские князья и члены верхних общественных слоев Западной Европы руководствовались сходными «правилами игры».

Ключевые слова: Древняя Русь, летописание, Владимир Мономах, история эмоций, эмоциональное сообщество, компаративистика

Литература, использованная в статье:

Грушевский, Михаил Сергеевич. История Украины-Руси. Т. 2. Лвів: Навуково товариство имени Шевченка, 1905. $602 \mathrm{c.}$

Литвина, Анна Федоровна; Успенский, Федор Борисович. О возможных мотивах одного политического убийства (XI в.) // Вспомогательные исторические дисциплины в современном научном знании: Материалы XXVIII Международной научной конференции. Москва: Аквилон, 2016. С. 35-40. Лукин, Павел Владимирович. Праздник, пир и вече: К вопросу об архаических чертах общественного строя восточных и западных славян // Одиссей: человек в истории. 2006. Феодализм перед судом историков. Москва: Институт всеобщей истории РАН, 2008. С. 134-150.

Назаренко, Александр Васильевич. Родовой сюзеренитет Рюриковичей над Русью (X-XI вв.) // Древнейшие государства на территории СССР. 1985 год. Москва: Наука, 1986. С. 149-157.

Althoff, Gerd. Spielregeln der Politik im Mittelalter. Kommunikation in Frieden und Fehde. Darmstadt: Primus Verlag, 1997. 360 p.

Bloch, Marc. La sociéte féodale: La formation des liens de dépendance. Paris: Editions Albin Michel, 1949. $287 \mathrm{p}$.

Bynum, Caroline. Jesus as Mother and Abbot as Mother: Some Themes in Twelfth-Century Cistercian Writing // Jesus as Mother: Studies in the Spirituality of the High Middle Ages. Berkeley: University of California Press, 1982. P. 110-169.

Cheyette, Frederick; Chickering, Howell. Love, Anger, and Peace: Social Practice and Poetic Play in the Ending of Yvain // Speculum. 2005. Vol. 80. P. 75-117.

Débax, Hélène. La féodalité languedocienne aux Xie - XIIe siècles: serments, sommages et fiefs dans le Languedoc des Trencavel. Toulouse: Presses universitaires du Mirail, 2003. 407 p.

Franklin, Simon; Shepard, Jonathan. The Emergence of Rus', 750-1200. New York: Longman Publ., 1996. $472 \mathrm{p}$.

Habermas, Jürgen. The Structural Transformation of the Public Sphere: An Inquiry into a Category of Bourgeois Society. Cambridge, MA: MIT Press, 1991. 301 p.

Heal, Felicity. Hospitality in Early Modern England. Oxford: Clarendon Press, 1990. 476 p.

Hinterberger, Martin. Emotions in Byzantium // A Companion to Byzantium. Malden MA: Wiley-Blackwell Publ., 2010. P. 123-134.

Hyams, Paul. Was There Really Such a Thing as Feud in the High Middle Ages? // Vengeance in the Middle Ages: Emotion, Religion and Feud. Farnham, U. K.: Ashgate Publ., 2010. P. 151-166.

Jones, George. The Ethos of the Song of Roland. Baltimore: Johns Hopkins University Press, 1963. 453 p. Jordan Fantosme's Chronicle. New York: Oxford University Press, 1981. 214 p.

McSheffrey, Shannon. Marriage, Sex and Civic Culture in Late Medieval London. Philadelphia: University of Pennsylvania Press, 2006. 304 p.

Mikhailova, Yulia. «Christians and Pagans» in the Chronicles of Pre-Mongolian Rus: Beyond the Dichotomy of «Good Us» and «Bad Them // Geschichte der Slavia Asiatica: Quellenkundliche Probleme. Leipzig: Leipziger Universitätsverlag, 2013. P. 50-79. 
Miller, William Ian. Humiliation: And Other Essays on Honor, Social Discomfort, and Violence. Ithaca, New York: Cornell University Press, 1995. 270 p.

Rees, Davies. «The Medieval State: The Tyranny of a Concept?» // Journal of Historical Sociology. (2003). Vol. 16. P. $280-300$.

Roche, Thomas. The Way Vengeance Comes: Rancorous Deeds and Words in the World of Orderic Vitalis // Feud, Violence and Practice: Essays in Medieval Studies in Honor of Stephen D. White. Burlington, VT: Ashgate Publ., 2010. P. 115-136.

Rosenwein, Barbara. Emotional Communities in the Early Middle Ages. Ithaca, New York: Cornell University Press, 2007. 228 p.

Rosenwein, Barbara. Eros and Clio: Emotional Paradigms in Medieval Historiography // Mediävistik im 21. Jahrhundert: Staat und Perspektiven der internationalen und interdisziplinaren Mittelalterforschung. Munich: Fink Publ., 2003. P. 427-441.

Rosenwein, Barbara. Even the Devil (Sometimes) Has Feelings // The Haskins Society Journal. 2005. Vol. 14. P. 1-14.

Stuard, Susan. Women in Medieval Society. Philadelphia: University of Pennsylvania Press, 2012.

White, Stephen. The Politics of Anger // Anger's Past: The Social Uses of an Emotion in the Middle Ages. Ithaca: Cornell University Press, 1998. P. 127-152.

Information about the article

Author: Mikhailova, Yulia Aleksandrovna - Assistant Professor, New Mexico Institute of Mining and Technology, New Mexico, USA, yulia.mikhailova@nmt.edu

Title: «He Sighed from His Heart and Began to Gather Soldiers»: Emotions in Russian Political Narratives Summary: Political functions of demonstrative emotional behavior have been extensively studied by Western medievalists, but little, if at all, discussed by scholars of Rus. This article offers an analyis of representations of emotions in Russian political narratives; it is informed by the concept of Spielregeln («rules of play»), developed by the German historian Gerd Althoff, and by application of anthropological theories to the medieval studies practiced by Anglophone scholars, such as Stephen White and Paul Hyams. These historians showed that societies lacking explicit normative documents regulated political and social interaction by means of implicit «rules of play» manifested in ritual behaviors. Public display of emotions was probably the most prominent among such behaviors. A comparison of information derived from Russian primary sources with the picture that emerges from scholarly literature on emotions in political narratives of the high medieval West suggests that social functions of emotions and the ways to send a political message by means of public emotional display were essentially the same in Rus and Latin Europe.

Keywords: Rus, chronicles, emotions history, emotional communities, comparative studies, Vladimir Monomakh

References

Althoff, Gerd. Spielregeln der Politik im Mittelalter. Kommunikation in Frieden und Fehde. Darmstadt: Primus Verlag, 1997. 360 p.

Bloch, Marc. La sociéte féodale: La formation des liens de dépendance. Paris: Editions Albin Michel, 1949. $287 \mathrm{p}$.

Bynum, Caroline. Jesus as Mother and Abbot as Mother: Some Themes in Twelfth-Century Cistercian Writing, in Jesus as Mother: Studies in the Spirituality of the High Middle Ages. Berkeley: University of California Press, 1982. P. 110-169.

Cheyette, Frederick; Chickering, Howell. Love, Anger, and Peace: Social Practice and Poetic Play in the Ending of Yvain, in Speculum. 2005. Vol. 80. P. 75-117.

Rees, Davies. «The Medieval State: The Tyranny of a Concept?», in Journal of Historical Sociology. (2003). Vol. 16. P. $280-300$.

Débax, Hélène. La féodalité languedocienne aux Xie - XIIe siècles: serments, sommages et fiefs dans le Languedoc des Trencavel. Toulouse: Presses universitaires du Mirail, 2003. 407 p.

Franklin, Simon; Shepard, Jonathan. The Emergence of Rus', 750-1200. New York: Longman Publ., 1996. $472 \mathrm{p}$.

Habermas, Jürgen. The Structural Transformation of the Public Sphere: An Inquiry into a Category of Bourgeois Society. Cambridge, MA: MIT Press, 1991. 301 p.

Heal, Felicity. Hospitality in Early Modern England. Oxford: Clarendon Press, 1990. 476 p. 
Hinterberger, Martin. Emotions in Byzantium, in A Companion to Byzantium. Malden MA: Wiley-Blackwell Publ., 2010. P. 123-134.

Hrushevskiy, Mykhailo Serhiyovych. Istoriya Ukrainy-Rusi [History of Ukraine-Rus]. Lviv: Naukovo Tovaristvo imeni Shevchenka Publ., 1905. Vol. 2. 602 p. (in Ukrainian).

Hyams, Paul. Was There Really Such a Thing as Feud in the High Middle Ages?, in Vengeance in the Middle Ages: Emotion, Religion and Feud. Farnham, U. K.: Ashgate Publ., 2010. P. 151-166.

Jones, George. The Ethos of the Song of Roland. Baltimore: Johns Hopkins University Press, 1963. 453 p. Jordan Fantosme's Chronicle. New York: Oxford University Press, 1981. 214 p.

Litvina, Anna Fyodorovna; Uspenskiy, Fyodor Borisovich. O vozmozhnykh motivakh odnogo politicheskogo ubiystva (XI v.) [On possible motives of one eleventh-century assassination], in Vspomogatel'nye istoricheskie distsipliny $v$ sovremennom nauchnom znanii: Materialy XXVIII Mezhdunarodnoy nauchnoy konferentsii [Auxiliary historical disciplines in the modern scientific knowledge: Proceedings of the XXVIII International Scientific Conference]. Moscow: «Akvilon» Publ., 2016. P. 35-40 (in Russian).

Lukin, Pavel. Prazdnik, pir i veche: k voprosu ob arkhaicheskikh chertakh obshchestvennogo stroya vostochnykh i zapadnykh slavyan [Feast and Assembly: On archaic social practices of East and West Slavs], in Odissey: Chelovek v istorii. 2006. Feodalizm: ponyatie i realii [Odysseus: A Man in History. 2006. Feudalism: The concept and the reality]. Moscow: Institute of World History (RAS) Press, 2008. P. 163-179 (in Russian). McSheffrey, Shannon. Marriage, Sex and Civic Culture in Late Medieval London. Philadelphia: University of Pennsylvania Press, 2006. 304 p.

Mikhailova, Yulia. «Christians and Pagans» in the Chronicles of Pre-Mongolian Rus: Beyond the Dichotomy of «Good Us» and «Bad Them, in Geschichte der Slavia Asiatica: Quellenkundliche Probleme. Leipzig: Leipziger Universitätsverlag, 2013. P. 50-79.

Miller, William Ian. Humiliation: And Other Essays on Honor, Social Discomfort, and Violence. Ithaca, New York: Cornell University Press, 1995. 270 p.

Nazarenko, Aleksandr Vasilyevich. Rodovoy syuzerinetet Ryurikovichey nad Rusyu (X-XI vv.) [Collective lordship of the Riurikid clan over Rus in the tenth and eleventh centuries], in Drevnie gosudarstva na territorii SSSR, 1985 god [The ancient states on the territory of the USSR, 1985]. Moscow: Nauka Publ., 1986. P. $149-157$.

Roche, Thomas. The Way Vengeance Comes: Rancorous Deeds and Words in the World of Orderic Vitalis, in Feud, Violence and Practice: Essays in Medieval Studies in Honor of Stephen D. White. Burlington, VT: Ashgate Publ., 2010. P. 115-136.

Rosenwein, Barbara. Even the Devil (Sometimes) Has Feelings, in The Haskins Society Journal. 2005. Vol. 14. P. 1-14.

Rosenwein, Barbara. Eros and Clio: Emotional Paradigms in Medieval Historiography, in Mediävistik im 21. Jahrhundert: Staat und Perspektiven der internationalen und interdisziplinaren Mittelalterforschung. Munich: Fink Publ., 2003. P. 427-441.

Rosenwein, Barbara. Emotional Communities in the Early Middle Ages. Ithaca, New York: Cornell University Press, 2007. 228 p.

Stuard, Susan. Women in Medieval Society. Philadelphia: University of Pennsylvania Press, 2012.

White, Stephen. The Politics of Anger, in Anger's Past: The Social Uses of an Emotion in the Middle Ages. Ithaca: Cornell University Press, 1998. P. 127-152. 